\title{
Retraction: Experimental orthotopic transplantation of a tissue-engineered oesophagus in rats
}

Sebastian Sjöqvist, Philipp Jungebluth, Mei Ling Lim, Johannes C. Haag, Ylva Gustafsson, Greg Lemon, Silvia Baiguera, Miguel Angel Burguillos, Costantino Del Gaudio, Antonio Beltrán Rodríguez, Alexander Sotnichenko, Karolina Kublickiene, Henrik Ullman, Heike Kielstein, Peter Damberg, Alessandra Bianco, Rainer Heuchel, Ying Zhao, Domenico Ribatti, Cristián Ibarra, Bertrand Joseph, Doris A. Taylor $\&$ Paolo Macchiarini

Nature Communications 5:3562 doi: 10.1038/ncomms4562 (2014); Published 15 Apr 2014; Updated 21 Mar 2017

This Article is retracted by the authors. Nature Communications previously issued an Editorial Expression of Concern (http://www.nature.com/articles/ncomms13310) related to this Article, following the publication of a report commissioned by The Karolinska Institute and prepared by the Expert Group for Misconduct in Research at the Swedish Central Ethical Review Board. Owing to the technical issues raised by this investigation, we, the authors, are now retracting the Article.

P.M., S.S., Y.G., S.B., M.A.B., C.D.G., A.S., K.K., H.K., P.D., A.B., R.H., D.R., C.I., B.J. and D.A.T. agree with this retraction. P.J., M.L.L., J.H., G.L., A.B.R., H.U. and Y.Z. could not be reached for comment.

This work is licensed under a Creative Commons Attribution 4.0 International License. The images or other third party material in this article are included in the article's Creative Commons license, unless indicated otherwise in the credit line; if the material is not included under the Creative Commons license, users will need to obtain permission from the license holder to reproduce the material. To view a copy of this license, visit http://creativecommons.org/licenses/by/4.0/
}

(C) The Author(s) 2017 